\title{
REALITAS KEHIDUPAN SOSIAL \& KEAGAMAAN BAGI MASYARAKAT WAMENA DI LEMBAH BALIEM KAB. JAYAWUAYA IRIAN JAYA*
}

\section{Oleh : ABUBAKAR TJANENG**}

\section{PENDAHULUAN}

Pembangunan sektor Agama dalam pelita $\mathrm{V}$ diarahkan untuk menciptakan tiga kondisi ideal, yakni (1) kader keimanan dan ketaqwaan yang tinggi. (2) Wawasan keberagamaan yang luas dan matang, (3). Kerukunan kehidupan beragama yang mantap dan dinamis untuk mensukseskan pembangunan nasional.

Agama sebagai salah satu bahagian dari pranata sosial merupakan aturanaturan yang berkenaan dengan kedudukan dan penggolongan dalam suatu struktur yang mencakup satuan-satuan kehidupan sosial, dan mengatur peran serta berbagai hubungan kedudukan dan peranan dalam tindakan-tindakan dan kegiatan kegiatan yang dilakukan. Yang paling banyak dalam kehidupan manusia ialah bagaimana peranan agama dalam kehidupan keluarga, karene di dalamnya tercipta hubunganhubungan yang meliputi kebutuhar. hubungan kelamin (perkawinan) kemesraan, cinta kasih, makan dan minum, pakaian dan berbagai kegiatan ekonomi.

\# Makalah ini diajukan pada seminar hasil penelitian yang diselenggarakan oleh Balai Penelitian Lektur keagamaan Ujung Pandang pada tanggal 7 Pebruari 1994

\#\# Peneliti di Balai Penelitian Lektur Keagamaan Ujung Pandang.
Antara aturan-aturan agama dan aturan-aturan adat, sering terjadi perbedaan bahkan dapat meningkat sebagai pertentangan, di samping adanya persamaan, karena aturan-aturan adat lahir dari masyarakat itu sendiri. Sedangkan aturan-aturan agama adalah datangnya dari Tuhan. Narnun demikian kedua aturan itu telah menjadi pedoman sikap dan tingkah laku orang«suku Dani di lembah Baliem Wamena dalam berbagai tindakan dan hubungan sosialnya. Bagaimana corak kehidupan sosial keagamaan mereka berdasar kedua aturan tersebut perlu diungkapkan.

Pengumpulan data dalam penelitian ini menggunakan teknik wawancara, pengamatan dan penelusuran data sekunder. Wawancara dilakukan terhadap para pemuka masyarakat (kepala-kepala Suku besar dan kecil ), pemuka Agama yang terdiri dari pengurus-pengurus lembaga Islam dan beberapa tokoh agama lainnya yang dianggap memberikan data yang akurat, dan pejabat-pejabat pemerintah Wamena.

Pengamatan dilakukan dengan sistem terlihat langsung dalam mengamati tingkah laku kehidupan sosial mereka yang berkaitan dengan kehidupan keagamaan. Juga penelusuran data sekunder sebagai rujukan di lapangan.

Data yang diperoleh, dianalisis dengan metode kualitatif deskriptif.

No. 11 Th. VI Juli/Dcscmber I'W4 


\section{KEHIDUPAN SOSIAL BUDAYA SUKU DANI}

Profil Kecamatan Wamena

Letak Wamena berada dalam 05" 12 Lintang Selatan dan $141^{\circ}$ Bujur Timur. (sebagai ibukota kabupaten daerah Tingkat II Jayawijaya ). Kecamatan Wamena adalah salah satu kecamatan dari 12 kecamatan di Jayawijaya yang berbatas; sebelah Utara gunung Trikora, sebelah Seiatan kecamatan Karuku, sebelah Barat Tion Asologima dan sebelah Timur Kurima. Jarak tempuh dari kecamatan Wamena ke kecamatan lain antara $16 \mathrm{~km}$ sampai $250 \mathrm{~km}$ dengan melalui pesawat udara. Sedangkan untuk mencapai Wamena dari Jayapura diperlukan waktu 40-45 menit dengan pesawat udara yaitu jenis penerbangan Merpati pk. 27, Hercules dan pesawat-pesawat perusahaan tertentu. Hubungan darat JayapuraWamena sampai saat ini belum tembus dengan jarak kurang lebih $750 \mathrm{~km}$. Kecamatan Wamena terbagi 19 desa dengan penduduk 24.376 laki-laki dan 21.306 perempuan, jumlah seluruhnya 45.682 jiwa (hasil registrasi 1992). Penduduk tersebut terkelompok dalam 11.983 atau rata-rata orang berumah tangga dan penduduk tersebut terdapat warga Negara Asing (WNA) 24 jiwa dan selebihnya adalah WNI.

Untuk sarana peribadatan telah tersedia rumah-rumah ibadah, Islam 5 buah, Protestan 120 dan Katolik 46 buah.

\section{Pemerintahan Adat}

Suku Dani mengenai adanya pemerintah adat yang sudah lama yaitu sejak dari nenek moyang mereka. Saat ini dengan adanya Republik Indonesia Pemerintahan adat mengalami perubahan berangsur-angsur mengacu dan tunduk pada tata pemerintah Indonesia.

Pada dasarnya pemerintah adat dipegang oleh Kepala Suku Besar, dalam bahasa Dani disebut Apkainkok dengan dibantu oleh seorang pangiima perang. Dalam pemerintahan wilayah kepala Suku Besar dibantu oleh kepala-kepala suku sesuai dengan pembagian / jumlah wilayah, seterusnya ke bawah dibantu oleh Kepala Suku Kecil dalam wilayah disebut agot atau kepala kampung.

Struktur / bagan organisasi pemerintah suku Dani dikemukakan mulai dari Apkainkok (kepala Suku Besar), Wimtugav (pangiima Perang), apkain (Kepala Suku Adat). agot (Kepala Suku Kecil), kepala keluarga dan rakyat.

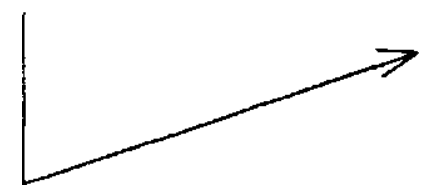




\author{
APKAINKOK
}

$\wedge$ WIMTUGAR

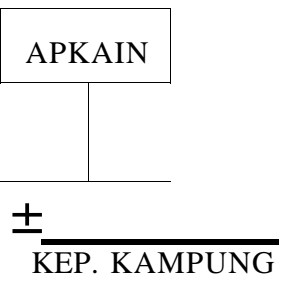

\section{APKAIN}

KEP. KAMPUNG
APKAIN

KEP. KAMPUNG
APKAIN

\author{
KEP. KAMPUNG
}

\title{
Keterangan :- Garis komando Garis koordinator
}

Kepala Suku Besar adat titik sentral dan dituakan, tempat pemecahan semua persoalan adat yang sifatnya besar, dan juga merupakan pimpinan Pesta Adat secara wilayah. Mereka bersama-sama Kepala Suku Kecil yang dituakan sebagai tempat pemecahan semua persoalan dalam wilayah masing-masing serta memimpin pesta adat di wilayahnya. Kepala Suku berfungsi dalam hal adat dan menyelesaikan persoalan-persoalan adat (bersifat rituil), sedangkan penguasaan tanah ada pada agot dan apkain, Kepala Suku Besar hanya berkuasa atas tanah keluarganya. apkainkok tidak mutlak turun temurun tergantung kepada anak calon penggantinya, biasanya harus melalui musyawara dengan beberapa persyaratan yaitu : (1) keturunan Kepala Suku, (2) Jago dan berwibawa, membunuh banyak musuh dalam peperangan dan (3) Kesaktiannya tinggi dan memiliki barangbarang "Wesa", (tempat menyimpan benda-benda keramat) seperti kampak batu nenek moyang, tengkorak-tengkorak musuh dan barang-barang jimat "kaneke".

Pemilihan dilakukan dalam suatu bentuk Pesta Adat yang diadakan khusus untuk itu (Warn Eweako).

Dalam menjalankan tugasnya sehari-hari, kepala Suku Besar mengadakan pesta adat secara besar-besaran, menyatakan perang dan perdamaian, menyelesaikan masalah yang tidak dapat diselesaikan oleh kepala Suku adat.

Panglima Perang, pembantu utama dari kepala suku besar dalam melaksanakan tugas kewengan yang dilimpahkan oleh Kepala Suku Besar menjalankan perang terhadap lawan dengan tekad menang. Perang itu dipandang Pengadilan Tertinggi dan Keputusan terakhir / tertinggi. Akibatakibat perang patut dihormati oleh semua suku dan semua Kepala Suku Besar yang berselisih.

Mereka dituakan dalam tingkat pertama untuk menyelesaikan persoalan-persoalan 
Sementara menanti mekanan sampai masak, mereka duduk berkelompok menurut keluarga masing-masing seraya membicakan bagaimana menyusun perencanaan perang dll. Bila makanan sudah masak, dibagikan kepada kelompok, sering juga ada yang tidak kebagian, dan sangat ironis kalau salah bagi, bisa berdampak pembunuhan.

\section{Pembakaran Mayat}

Jika seseorang meninggal segera disampaikan kepada kepala Suku, kemudian diumumkan secara berantai, orang-orang yang mendengarkan segera pergi mengumpulkan kayu kering untuk pembakaran mayat, kayu disusun secukupnya sehingga kira-kira 1,20 meter. Orang-orang yang melayat membawa babi, ubi dan sayur-sayuran sebagai sumbangan kepada keluarga yang ditimpa kemalangan.

Biasanya mayat sebelum dibakar didudukan dikursi darurat yang terbuat dari kayu. Sekitar pukul 14.00 mayat bersama kursinya diusung ketempat pembakaran, kemudian ditimbuni kayu bakar dan alang-alang dan setelah api menyala banyak famili terdekat memotong jari dan telinganya sebagai tanda berkabung. Setelah pembakaran usai, debu jenazah dikumpulkan dan dibungkus dengan kulit kayu kemudian digantungkan di atas tungku di dalam honay, potongan jari dan telinga tadi digantung bersamasama.

Sebagian penduduk yang sudah memeluk agama Kristen tidak lagi melakukan seperti tersebut, namun pembakaran mayat masih berlaku, hanya saja debu atau tuiang ditanam dekat pembakaran kemudian ditanami bungabunga disekitarnya.

Di lembah Baliem ada dua mumi yang terkenal dan masih sering dikunjungi oleh orang dari luar Wamena, mereka adalah suku Dani yaitu (1) Mumi I nama aslinya Weletak, mumi ini adalah mayat yang dikeringkan atau diawetkan sejak lama, konon kabarnya mumi tersebut sudah 1 (satu) abad lamanya, masih sempt dipamerkan dalam keadaan duduk di kursi, mumi ini bertempat tinggal dalam Honai di Akima kurang $7 \mathrm{~km}$ dari kota Wamena. Dalam Honai itu kepala sukunya bernama Elosak yang terdiri dari 5 kepala keluarga di Honai (perkampungan) tersebut. (2) Mumi II, nama aslinya Konono Mabel bertempat tinggal di Wibinionto, kurang lebih $20 \mathrm{~km}$ dari pusat kota Wamena. Juga sudah berumur lebih satu abad lamanya.

\section{- Makanan dan Kesehatan}

Makanan pokok suku Dani adalah ubi jalar, mereka menyebutnya hipere, petatas atau boneng, karena di lembah Baliem punya banyak bahasa, Mereka belum berani makan makanan yang mereka belum kenal karena alasannya takut mati. Juga masih tradisional dalam hal memasak yaitu dengan nama bakar batu, mereka belum kenal berbagai bumbu masak dan santan, tidak heran jika suku Dani tidak memiliki piring atau peralatan masak lainnya.

Pemelihara kesehatan masih sangat sederhana, seperti jika mereka sakit hanya menggunakan pisau untuk menorehkan dikepalanya hingga keluar darah, ternyata dapat sembuh.

\section{- Tempat Tinggal}

Selain masakan makanan dan kesehatan, juga tempat tinggal suku Dani masih sangat tradisional. Rumah Suku Dani disebut Hinai. Dinding Honai terbuat dari papan Cincang dan atapnya dari 
rumbia.

Honai untuk pria dan Honai untuk wanita untuk wanita bentuknya berbeda. Rumah untuk pria berbentuk bulat dan berlantai dua. Bagian bawah untuk perapian yang merangkap ruang santai dan ruang tamu. Bagian atas digunakan untuk tidur. Karena adanya perapian di lantai bawah, lantai dua menjadi hangat.

Ruang tidur laki-laki dan wanita terpisah. Bentuk rumah untuk wanita memanjang dan satu lantai. Rumah wanita biasanya digunakan juga untuk memasak dan kandang babi. Dimata suku Dani, babi adalah hewan yang sang^t berharga. Karena itu tidak jarang kita temu babibabi yang masih kecil digendong ke sana kemari oleh para wanita, anak-anak, atau para laki-laki.

Penduduk Suku Dani yang tinggal di pelosok belum begitu mengenal mata uang. Maka mereka kebanyakan hanya mengenal uang kertas seratus rupiah yang berwarna merah saja.

\section{ISLAM DI WAMENA}

Dalam perjalanan sejarah masuknya Islam di Wamena bermula di daerah FakFak lalu ke daerah Kaimanga kemudian ke daerah Jayapura. Hal ini didasarkan dalam naskah serah terima (memorial Van Overgave) pada pejabat pemerintah.

Masuknya Islam ke daerah Fak-Fak diperkirakan sejak tahun 1606 (dalam perjalanan penjajahannya pelaut Louis Vaes de Torres). Para pendagang Islam yang datang di pantai Irian Jaya umumnya berasal dari Tidore, Ternate dan Makassar. Hal ini disebabkan karena tahun 1667 Tidore monopoli Irian Jaya temasuk Sulawesi (Sartono Kartodirjo 1987; 264).

Perkembangan agama Islam berjalan terus, terutama pada tahun 1912 banyak orang menganut agama Islam, bahkan 13 tahun kemudian penduduk desa Wagom dan Sekru berali ke agama Islam, termasuk juga di Jayapura (Hollandia atau kota baru dahulu) dan kampung cina (J. J. W. Dubois, 1961; 35). Haji Abdul Madjid yang berasal dari Tidore adalah seorang Muslim pertama yang tinggal menetap di Jayapura (1910-1925) dan menjadi Imam disitu kemudian digantikan oleh imam Rakib yang berasal dari Ambon, selanjutnya berturut-turut digantikan oleh Hamissi Asmat dan Akil Sidik dari Ternate yaitu sejak 1930, Akil Sidik meninggal 1943 dan untuk sementara digantikan oleh Abubakar Nassa pada tahun 1949 diangkat sebagai Imam oleh Residen (J. J. W. Dubois, 1961; 35 - 36)

Pada awalnya di Wamena yang menjadi penganut Islam pada umumnya adalah pendatang, sejak adanya hubungan Jayapura dengan Wamena. Sedangkan agama kristen lebih awal dikenal oleh mereka, melalui penyiaran agama kristen dari orang-orang Belanda sebagai sending.

Suku Dani di lembah Baliem baru mengenal Islam pada tahun 1974, setelah masuknya Islam yang bernama Masubon. Pada saat ini yang mengislamkan adalah salah seorang Anggota ABRI (Kodim) yang bernama Kamaruddin dan kebetulan juga anggota DPRD II di daerah itu. Dengan masuknya Masubon dalam agama Islam berangsur-angsurlah suku Dani masuk Islam, sehingga sampai saat diadakan penelitian Desember 1993 jumlah suku Dani masuk Islam 487 orang, mereka tergolong sebagai muallab.

Umat Islam pendatang aktif melakukan / menyampaikan Dakwah Islamiyah, bahkan membentuk macammacam wadah / lembaga Islam seperti; 
1. YAPI (Yayasan Pendidikan Islam)-, berdiri sejak tahun 1970 di Jayapura sebagai pusat. Sedangkah di daerah Wamena berdiri pada tahun 1974, dengan suatu kepengurusan yang terdri sebagai ketua berturut-turut sampai tahun 1989 Abdul Latif, Abdullah DM dan $\mathrm{H}$. Burhanuddin Marsuki; sekretaris Drs. Aminuddin Jabil dan Bendahara adalah Rustam kepengurusan tersebut berlangsung sampai sekarang

2. YADAI (Yayasan Dakwah Islamiyah), berdiri sejak 1974 dan dipimpin oleh ketuanya $\mathrm{H}$ Marwan yang berasal dari Jawa dan Wakilnya bernama Mustapa Kemal, berasal dari Palopo Sulawesi Selatan dan bekerja di pemerintahan. Kegiatannya banyak mengurusi Da'i, bahkan mendatangkan dari luar.

3. ISLAMIC SENTER, berdiri sejak 1979, mempunyai pengurus lengkap yang dipimpin oleh ketuanya Hasan Panjaitan wakilnya Drs. Ramli dan Jumiati. Sekretarisnya adalah Yahya Muhammad dan bendahara dipercayakan kepada Basri. Tujuan Islamic ini adalah mengkoordinir umat, dakwah, Majelis Ta'lim, tempat ibadah, Pendidikan dll.

4. MDI (Majelis Da'wah Islamiyah), berdiri sejak terbentuknya GOLKAR, namun nanti aktif pada tahun 1980-an, organisasi ini dipimpin oleh Mundikun dan wakilnya B. Marsuki, sekretaris Amiruddin Jabir.
5. Rumah Ibadah

a. Masjid Baiturrahiem, berlokasi di komplex Kodim, dipimpin oleh Imam Abuyani (Ketua MUI daerah Ke II Jayawijaya)

b. Masjid Nurul Hidayah" berdiri sejak 1980 luas bangunan 12 x 17 meter, status tanahnya adalah tanah wakaf, sementara dipimpin oleh Abd. Majid.

c. Masjid "Agung Baiturrahman" berdiri sejak tahun 1990 dengan luas bangunan $17 \mathrm{X}$ 17 meter, adalah bantuan YABMP dan diketahui oleh Jumati.

6. Madrasah Ibtidaiyah, berdiri pada tahun 1978 status swasra, berkedudukan di desa Walesi. Di desa ini didirikan semacam Pilot Proyek Pendidikan Islam bagi orang Muallaf (suku Dani), berupa satu komplex, di dalamnya ada masjid permanen, perumahan guru dan kepala suku tempat praktek pemeliharaan ikan tawar, perkebunan dan peternakan.

Setiap saat mereka mendapat sumbangan berupa pakaian, makanan, terutama berasal dari luar Propinsi Irian. Jaya.

Dalam komplex, mereka dipimpin oleh kepala suku yang sudah masuk Islam tahun 1982 yaitu H. Aipon Asso, juga merangkap sebagai kepala perang. Dengan masuknya Islam Aipon Asso banyak pam yang ikut, terutama Pam Asso. Memang di Wamena (lembah Baliem) di samping banyak bahasa, juga banyak suku-suku kecil seperti suku (pam) Asso, Ubi, Oma, 
Watipe, Ikia, Kosai, Lagoan, Hilapok, Bakaro, Alua, Jibili, Wanitik Surabu, Jugusa, Walela, Siep, Elosa, Himan, Marian, dll.

Biasanya, kebanyakan masuk Islam apabila waktu pembagian zakat, bahkan banyak ikut-ikutan bejaka. Ini karena masih sangat terbatasnya tingkat pemikiran dan keyakinan mereka, sehingga mengajarkan ajaran-ajaran Islam masih sangat sulit. Berbagai da'wah yang dilakukan hasilnya sangat terbatas namun para Da'i tidak putus asa sebab mereka berpengharapan pada anak keturunan yang nantinya lebih mudah dibimbing. Lembagalembaga Islam nantinya ada mencurahkan perhatiannya kepada pembinaan para muallaf itu, agar bisa banyak tahu tentang ajaran-ajaran Islam.

\section{HI. PENUTUP}

Kondisi lokasi kecamatan Wamena yang biasa juga disebut Lembah Baliem agak berbeda dengan keadaan alam daerah-daerah lainnya, yaitu suatu kota kecil berada di tengah-tengah gunung belantara, sehingga penduduk sangat lambat melakukan adaptasi / integrasi dengan dunia modernisasi, utamanya penduduk asli. Perubahan persepsinya belum membawa dampak yang dapat mengancam hidup dan kehidupannya sebagai makhluk yang sonpolotikon.

Persentuhan antara nilai-nilai tradisional dengan modernisasi sangat didambakan oleh setiap yang mempunyai kepentingan, sehingga adanya sentra-sentra sosial yang perlu dipupuk. Demikian hal kondisi ideal pada tingkat perilaku, terasa bagaimana mungkin dapat menjadi kondisi ideal yang sama.

Pancaran termasuk terbukti pada suku Dani masih terbelakang dalam menganti- sipasi persoalan-persoalan religius. Agama Islam misalnya, belum terbaca suatu warna yang dapat dijadikan rujukan dalam menjatuhkan evaluasi, kecuali menjalankan amar-amar sebagaimana layaknya kewajiban umat Islam kepada sesamanya.

Pembukaan Warga suku Dani di Wamena perlu waktu lama untuk menembus poros-poros yang strategi sifatnya, seperti pendidikan terhadap anakanaknya sebagai generasi berikutnya. Demikian halnya pembinaan agama Islam yang menjadi sasaran adalah keturunan dan anaknya.

Warga pendatang yang berdomisili di Wamena berkewajiban melibatkan diri dalam proses sosialisasi, terutama dalam pelaksanaan ajaran a «ama yang dianutnya (Islam) sebagai panutan umat. Ini nampak dalam aktifitasnya dalam menumbuh kembangkan lembaga-lembaga/wadah Islami.

\section{DAFTAR PUSTAKA}

- Colletta, Nat. J. dan Umar Kayan (Penyunting) 1987

Kebudayaan dan Pembangunan, sebuah pendekatan terhadap Antropologie Terapan di Indonesia, yayasan Obor Indonesia, Jakarta.

- Kuntowijoyo, 1987, Budaya \& Masyarakat, Tiara Warna, Yokyakarta.

- Redfield, Robert, 1985,. Masyarakat Petani dan Kebudayaan Rajawali Press, Jakarta.

- Taneko, Solemana B 1984 Struktur Dan Proses Sosial, Rajawali Press, Jakarta. 